The only recent record for the Yorkton district, is a lone Whooper noted in the fall of 1942 with a flock of sandhills at Rokeby Marsh, by John Domon.

Even more interesting is the following account written about July 14-15, 1859 in "The Canadian Exploring Expeditions in Rupert's Land" by Henry Youle Hind, M.A., F.R.G.S., in charge of the Assiniboine and Saskatchewan expedition. "The white or whooping crane (Grus americana) was first seen today. This beautiful bird is common in the Qu'Anelle Valley and in the Touchwood Hill range. It is a dangerous antagonist when rounded, striking with unerring aim and great force with its powerful bill. When the bird is wounded, the best way to avoid its attacks is to present the muzzle of the gun as it approaches, it will fix its bill in the barrel and may then be destroyed without danfer. Instances have been known of this bird driving his bill deep into the bowels of a hunter when not successful in warding off its blow."

We would appreciate it if our "old-timer" members would write us concerning the status of the Whooping Crane in their district in the early days.

\title{
$\frac{\text { Review of a Field Guide to the Birds }}{\text { by Foger Tory Peterson. }}$
}

The highest award in the field of ornitholozy is the Brewster Medal, presented by the American Ornithologists Union to outstanding works on North American birds. The second edition of Roger Tory Peterson's now classic Field Guide to the Birds, won this distinguished award, partly because of its orisinal contribution to the field identification of birds and partly because it had interested more people in birds than any other book in recent years.

Now a third edition is off the press, and where the second edition was good, this one is even better. It is re-written, re-organized and every illustration is new. There are 1,000 illustrations and over 500 in full color. Mr. Peterson is already so well known for his paintings of birds, "especially those reproduced from time to time in "LIFE" that further comment as to the high quality of the illustrations should not be necessary.

We, of the Yorkton Natural History Society, feel that this book is a must for every member, as it is the last word in convenience and easy identification of birds. Peterson's famous system is based on nattern drawings, field marks, and comperisons between species. How many times have we noted a bird, and on being none too certain as to its identity, asked ourselves "What other bird could it have been?" Peterson's will give you the answer, and quickly, as all comparative species are shown on a single pase with all identification marks clearly pointed out. It covers too, all species that one is apt to see in Saskatchewan, except for a few stragslers from the Rocky Mountains or beyond.

A feature is the full-color drawings of the Warblers in immature and autumn plumeges, some so similar that they have always corfused even the experts, The Gulls and Terns, other difficult spevies, are also remarkably well shown in immature, winter, and breeding plumages.

For the sportsmen, the ducks and geese, due to the fact that they are more easily identified by pattern than by color, are shown in black and white in flight overhead and on the water, as well as in color. 
The book is $4 \frac{1}{2}$ inches by $7 \frac{1}{2}$ inches in size, and therefore easily carried afield in a good-sized pocket.

Nembers are cautioned not to confuse this book with "A Field Guide to Western Birds," a similar volume by the same author, which covers the Rocky Mountains and Pacific Coast regions (but not the prairies, as the title would lead some people to believe.) The dividing line between the ranges covered by the two books falls somewhere east of the foothills, and hence readers in Alberta, and possibly even extreme western Saskatchewan, may find that they need both books in order to cover their territory completely.

Peterson's "A Field Guide to the Birds" may be obtained through any book store for $\$ 3.50$. For beginner and expert alike, it cannot be recommended too highly.

\section{CHRISTHAS BIRD CENSUS}

For the sixth consecutive year we shall again be taking our annual Christmas Bird Census, and we hope that all who have taken part in the past, will ayain be out in force, as well as our many new members. These winter counts have resulted in some very interesting data concerning our winter birds, as well as being an excellent nastime for all those who take part.

The count should be made on any one day between Christmas and New Year inclusive. Every species of bird seen should be recorded as well as the total number of each species. Notes should also be made as to weather, wind, temperewie, depth of snow, rumber of miles travelled and the time the observer (s) spent, afield. It would also be very interesting to make notes concerning the food conditions, ie. the abundance (or scarcity) of hanging dried fruit, maple seeds and weed seeds, etc.

The previous five counts have resulted in 54 species, (or sub-species recognizable in the field) being recorded. For the convenience of members, the following is a list of all birds reported in our Christnas Census.

\section{Mallard Duck}

Goshawk

Common Rough-legged Hawk Marsh Hawk

Golden Eagle

Prairie Falcon

Soruce Grouse

Ruffed Grouse

Sharp-tailed grouse

Wijlow Ptamigan

Hungarian Tar', ricse

Ring-necked Phersint

Great Horned Owi

Snowy Owl

Long-eared Owl.

Short-eared Swl

Saw-whet Ow.

Pileated Woorbaker

Hairy Woodperisor

Dowry Woodpecker
Artic Three-toed Woodpecker

Amer. Three-toed Woodpecker

Borned Lark

Canada Jay

Blue Jay

American Magpie

Raven

Black-capoed Chickadee

Hudsonian Chickadee

Whaterisecred Nuthatch

Red rureasted Nuthatch

Brown uneper

Eestern Robin

Golden-crowned Kinglet

Bcheratan Waxwing

Nontrirn Shrike

Fir onfan Suarling

English Sparrow

Western Meadowlark

Rod-winged Blackbird
Brewer's Blackbird

Evening Grosbeak

Pine Grosbeak

Gray-crowned Rosy Finch

Hepburn's Rosy Finch

Hoary Redpoll

Common Redpoll

Red Crossbill

White-winged Crossbill

Slate-colcred Junco

Tree Sparrow

Song Sparrow

Lapland Longspur

Snow Bunting 